\title{
Spinal ganglion cyst presenting with radiculopathy: diagnostic challenges and differential
}

\author{
Lohit Velagapudi $i^{1}$ - Caio M. Matias ${ }^{1} \cdot$ Christopher Elia $^{1} \cdot$ David Stolzenberg ${ }^{2} \cdot$ Garrett Largoza $^{1} \cdot$ Rick Feld $^{3}$. \\ Mark Curtis ${ }^{4}$. James S. Harrop ${ }^{1}{ }^{1}$
}

Received: 19 October 2020 / Revised: 7 December 2020 / Accepted: 8 December 2020

(c) The Author(s), under exclusive licence to International Spinal Cord Society 2021

\begin{abstract}
Introduction Ganglion cysts are benign soft tissue lesions, usually arising from periarticular connective tissue. These are very rarely reported in the spine, but when seen can cause radiculopathy or myelopathy.

Case presentation A 68-year-old female patient presented with worsening radiculopathy and right foot drop and imaging noted a right L5-S1 foraminal mass. The lesion was gross totally resected. Histological analysis revealed myxoid degeneration and inflammation, without a synovial lining, consistent with ganglion cyst.

Discussion While uncommon, intra-foraminal ganglion cysts can be distinguished from synovial cysts through imaging and histology and are typically amenable to surgical resection. Greater knowledge and insight about differentiating ganglion versus synovial cyst may prevent resection of facet joints and prevent a fusion procedure.
\end{abstract}

\section{Introduction}

Ganglion cysts are common lesions in the musculoskeletal system arising from membranous and fibro-collagenous tissues, most commonly tendon sheaths and periarticular areas. While most common in the hand and wrist, they can also arise in any perineural connective tissues. When occurring in the spine often this leads to symptoms of spinal nerve root compression such as paresthesia and weakness [1-4]. We present the case of an intra-foraminal ganglion cyst leading to radiculopathy that was successfully treated with resective surgery.

Lohit Velagapudi

lohit.velagapudi@students.jefferson.edu

1 Department of Neurosurgery, Thomas Jefferson University, Philadelphia, PA, USA

2 Rothman Orthopedic Institute, Thomas Jefferson University, Philadelphia, PA, USA

3 Department of Radiology, Thomas Jefferson University, Philadelphia, PA, USA

4 Department of Pathology, Thomas Jefferson University, Philadelphia, PA, USA

\section{Case presentation}

A 68-year-old female presented to our institution with progressive right sided L5 radiculopathy for 2 months, rated as $9 / 10$ in the numerical rating scale, refractory to nonoperative management with new subacute onset of right foot drop. Oswestry Disability Index of 37 was noted with significant difficulty in activities of daily living due to her pain. Neurological exam was significant only for 3/ 5 strength of the right anterior tibialis muscle and $0 /$ 5 strength in the right extensor hallucis longus. Patient was noted to have an antalgic gait with limitations secondary to her foot drop.

MRI lumbar spine revealed a $19 \times 12 \times 11 \mathrm{~mm}$ T2 hyperintense mass in the right L5/S1 neural foramen contributing to mild spinal canal stenosis and severe foraminal narrowing (Figs. 1 and 2). This lesion was initially diagnosed as a perineural cyst; however, her symptoms were disproportional for a perineural cyst and therefore the hypothesis of a non enhancing or a schwannoma was deemed more likely. Synovial cyst was also included in the differential diagnosis but considered less likely due to lack of joint pathology or instability on flexion-extension films.

Patient underwent a right sided L5/S1 facetectomy (Fig. 2) for adequate exposure of the lesion. Intraoperative ultrasound revealed a nonvascular mass with cystic and solid components. The lesion had no visible connections 


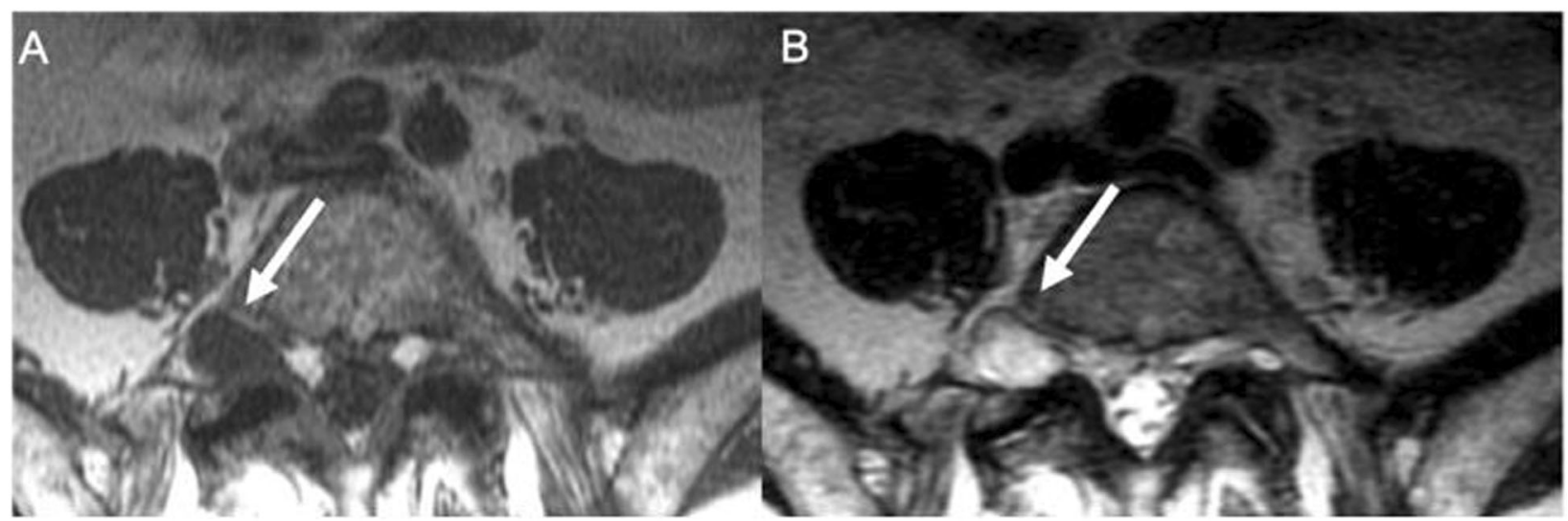

Fig. 1 Axial MRI imaging. A lesion (arrow) in the right L5-S1 foramen, hypointense on T1 weighted image (A), and hyperintense on T2 weighted image $(\mathbf{B})$ is seen.

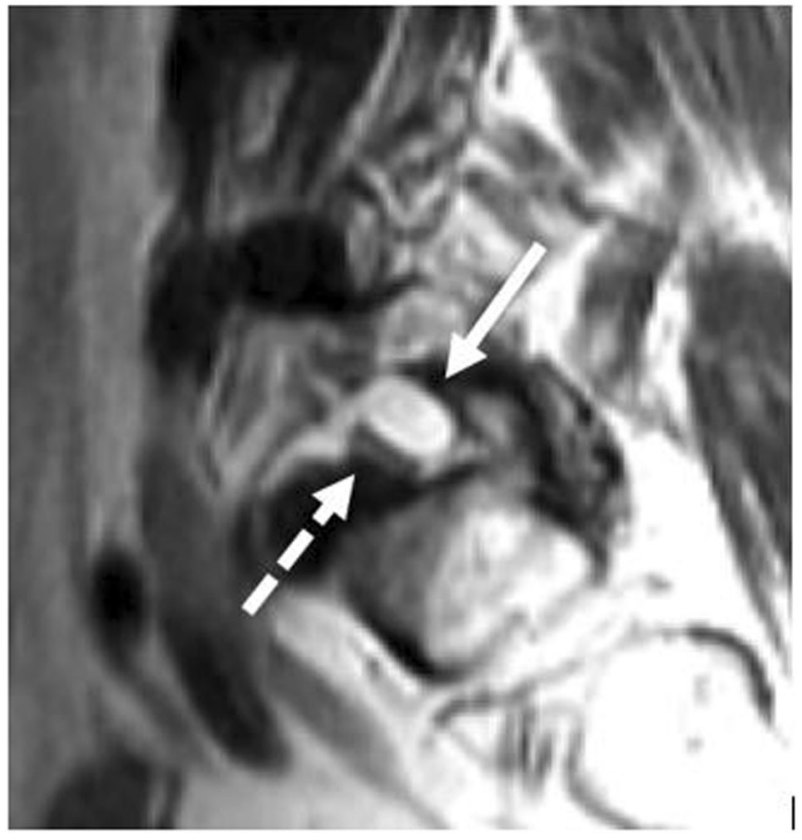

Fig. 2 Sagittal MRI imaging. Parasagittal T2 weighted image showing lesion (solid line arrow) compressing L5 nerve root (dash dot arrow) in the in foramen.

with surrounding ligamentous or periarticular tissue (Fig. 3). A plane between the nerve root and perineural mass was identified and it was removed en bloc (Fig. 4), achieving gross total resection. After removal, the right sided L5 and S1 nerve roots were examined, and both found to be intact.

Histological examination of the multiloculated cyst filled with yellow, viscous fluid revealed myxoid degeneration and inflammation, consistent with ganglion cyst (Fig. 5). No synovial lining was present, and S-100 testing was negative.

Postoperative course was uncomplicated, with immediate resolution of radiculopathy and improvement after 1 day of right tibialis anterior strength to $5 / 5$ and right extensor hallucis longus strength to $4 / 5$. No rehabilitation was required.

\section{Discussion}

Spinal cysts are typically related to the facet joints and a result of degeneration of the joint. However, "Ganglion cyst" and "synovial cyst" are separate pathological processes that can be distinguished histologically by the presence or absence of synovial lining [5-7]; unfortunately due to the infrequency and lack of knowledge ganglion and synovial cysts are often used interchangeably which can be source of confusion [8]. A synovial cyst is lined with pseudostratified columnar cells (synovial lining) and usually contains clear, serous, or xanthochromic fluid and communication with the joint cavity. In contrast, ganglion cysts lack this synovial cell lining, and have no communication with the joint cavity, with protein-rich viscous fluid due to myxoid degeneration of surrounding tissues, as seen in the presented histological analysis. In addition, these two histologically distinct structures have been combined under the umbrella term "juxtafacet cyst" [9-11]. The most supported pathogenesis of ganglion cysts has been herniation of the synovium into surrounding tissues [12]. Alternative pathogeneses proposed include chronic inflammation leading to myxoid degeneration of tissue, repeated microtrauma, or increased hyaluronidase production by a proliferation of mesenchymal cells [12-15].

Distinction between ganglion and synovial cysts using MRI is frequently not possible [8]. On imaging, ganglion cysts can be distinguished through a fibrous contrastenhancing capsule, although further differentiation from other cystic lesions requires gross and histological examination. In addition, imaging may be complicated by atypical cyst content such as debris or hemorrhage/hemosiderin 

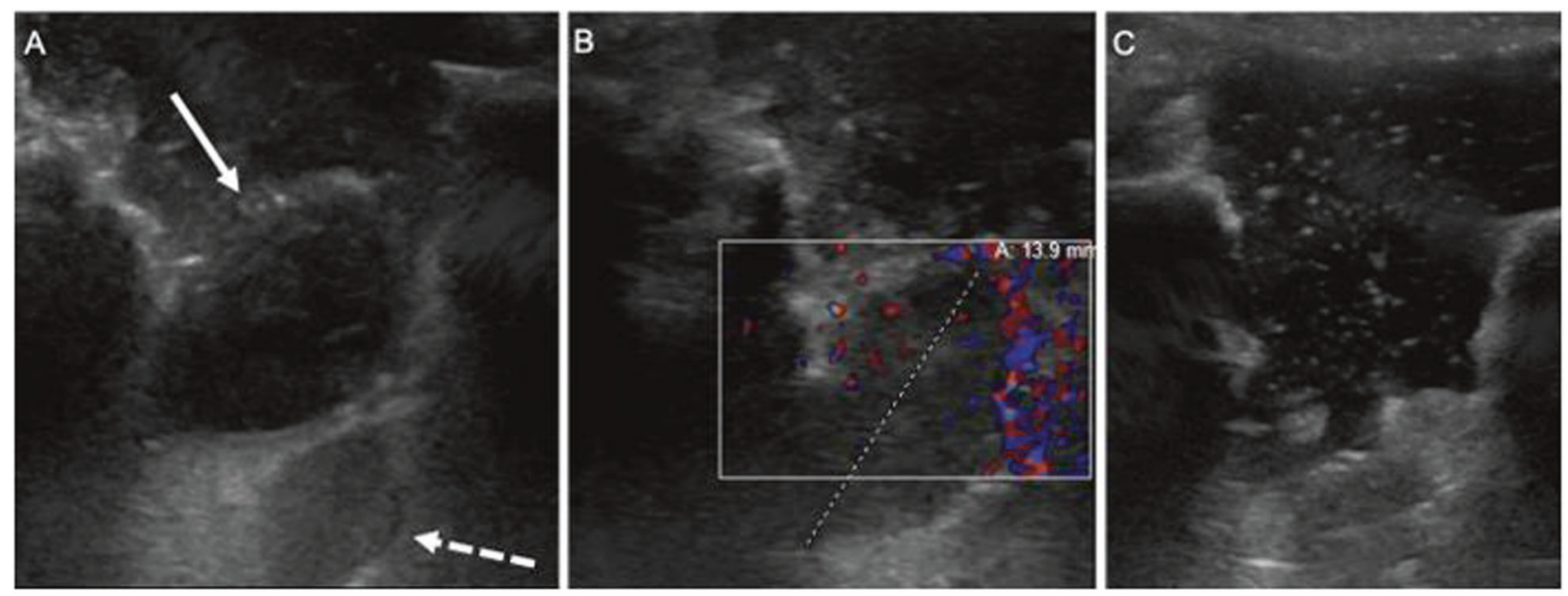

Fig. 3 Intaoperative ultrasound imaging. Intraoperative ultrasound (A) confirmed the lesion seen on MRI (solid line arrow) just dorsal to the nerve root (dash dot arrow). Color Doppler demonstrated no internal vascular flow (B) and following resection, ultrasound demonstrated the mass was completely removed $(\mathbf{C})$.

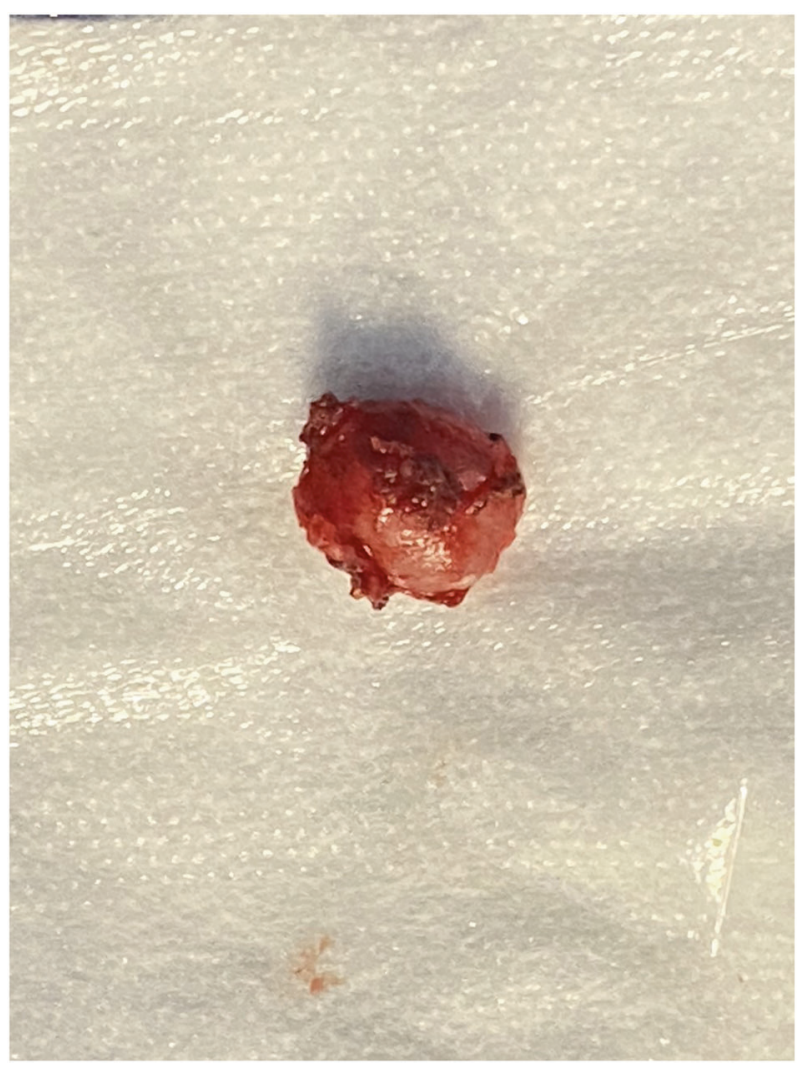

Fig. 4 Lesion gross appearance. A solid lesion was fully resected en bloc.

deposition, which can render a normally hypo or isointense T1 lesion a hyperintense aspect [16].

In clinical practice, these lesions are difficult to distinguish as both can cause symptoms of nerve root or spinal cord compression, neurogenic claudication, myelopathy,

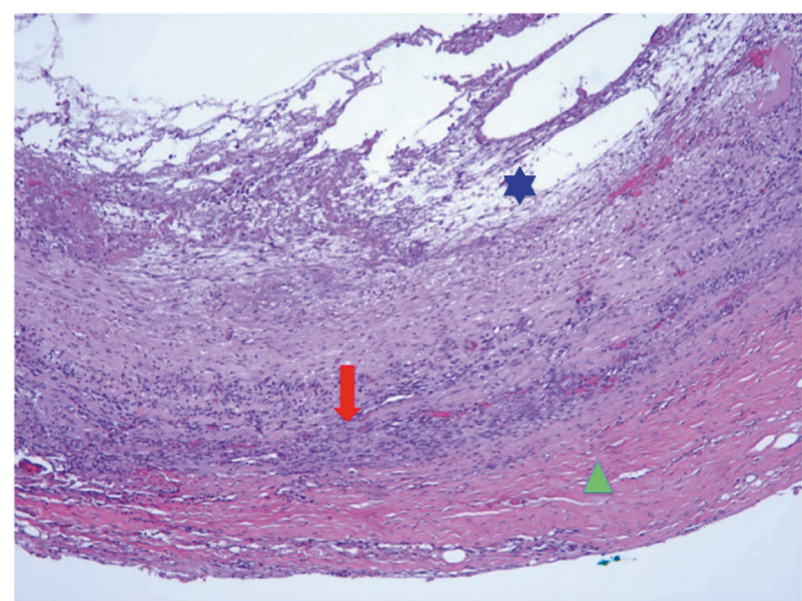

Fig. 5 Histologic examination of the ganglion cyst reveals a fibroconnective tissue wall (triangle) with area of mural reactive chronic inflammation (arrow), and myxoid degeneration that leads to cyst formation (star). Hematoxylin and eosin stain, original magnification $\times 100$.

cauda equina syndrome, or even Brown-Sequard syndrome depending on location and surrounding structures [17-19]. Intracystic hemorrhage in particular can lead to abrupt onset of symptoms out of proportion with the more expected chronic myxomatous degenerative disease process [20]. While spontaneous regression of ganglion cyst is rare, conservative management with analgesics, neuropathic pain management, and physical therapy can be used to treat patients without significant deficits. Although synovial cysts and ganglion cysts are separate pathological processes, they are managed similarly and both definitively treated with surgical decompression and resection with favorable outcomes in terms of functional status and recurrence [21-24]. 


\section{Conclusion}

Ganglion cysts are soft tissue lesions arising from periarticular tissue. While most common in the wrist and forearm, cysts in or around the spinal canal can lead to symptoms of radiculopathy or myelopathy. While ganglion cysts can appear similar to lesions such as synovial cysts on imaging, they have distinct histological characteristics. Although rare, ganglion cysts should be included in the differential diagnosis for $\mathrm{T} 2$ hyperintense spine lesions and are generally amenable to surgical resection with good clinical outcomes.

\section{Compliance with ethical standards}

Conflict of interest The authors declare that they have no conflict of interest.

Publisher's note Springer Nature remains neutral with regard to jurisdictional claims in published maps and institutional affiliations.

\section{References}

1. Schoellhammer L, Nielsen TW, Berg JO. Large ganglion cyst with unusual location on the back- a case report. Plast Reconstr Surg Glob Open. 2016;4:729. https://doi.org/10.1097/GOX. 0000000000000746

2. Kim SW, Choi JH, Kim MS, Chang CH. A ganglion cyst in the second lumbar intervertebral foramen. J Korean Neurosurg Soc. 2011;49:237-40. https://doi.org/10.3340/jkns.2011.49.4.237.

3. Lyons MK, Atkinson JLD, Wharen RE, Deen HG, Zimmerman RS, Lemens SM. Surgical evaluation and management of lumbar synovial cysts: the Mayo Clinic experience. J Neurosurg. 2000;93:53-7. https://doi.org/10.3171/spi.2000.93.1.0053.

4. Radatz M, Jakubowski J, Cooper J, Powell T. Synovial cysts of the lumbar spine: a review. Br J Neurosurg. 1997;11:520-4. https://doi.org/10.1080/02688699745673.

5. Domenicucci M, Ramieri A, Marruzzo D, Missori P, Miscusi M, Tarantino R, et al. Lumbar ganglion cyst: nosology, surgical management and proposal of a new classification based on 34 personal cases and literature review. World J Orthop. 2017;8:697-704. https://doi.org/10.5312/wjo.v8.i9.697.

6. Kim J, Choi J, Son B. Bilateral ganglion cysts of the ligamentum flavum in the cervical spine causing a progressive cervical radiculomyelopathy and literature review. Case Rep Neurol Med. 2017;2017:1-5. https://doi.org/10.1155/2017/3953641.

7. Yamamoto A, Nishiura I, Handa H, Kondo A. Ganglion cyst in the ligamentum flavum of the cervical spine causing myelopathy: report of two cases. Surg Neurol. 2001;56:390-5. https://doi.org/ 10.1016/S0090-3019(01)00639-5.

8. Neto N, Nunnes P. Spectrum of MRI features of ganglion and synovial cysts. Insights Imaging. 2016;7:179-86. https://doi.org/ 10.1007/s13244-016-0463-z.
9. Kao CC, Winkler SS, Turner JH. Synovial cyst of spinal facet. Case Rep J Neurosurg. 1974;41:372-6. https://doi.org/10.3171/ jns.1974.41.3.0372.

10. Stoodley MA, Jones NR, Scott G. Cervical and thoracic juxtafacet cysts causing neurologic deficits. Spine. 2000;25:970-3. https:// doi.org/10.1097/00007632-200004150-00012.

11. Song JK, Musleh W, Christie SD, Fessler RG. Cervical juxtafacet cysts: case report and literature review. Spine J. 2006;6:279-81. https://doi.org/10.1016/j.spinee.2005.09.006.

12. Cho SM, Rhee WT, Lee SY, Lee SB. Ganglion cyst of the posterior longitudinal ligament causing lumbar radiculopathy. J Korean Neurosurg Soc. 2010;47:298-301. https://doi.org/10. 3340/jkns.2010.47.4.298.

13. Giger R, Szalay-Quinodoz I, Haenggeli A, Dulguerov P. Ganglion cyst of the spinal anterior longitudinal ligament presenting as a retropharyngeal mass. Am J Otolaryngol Head Neck Med Surg. 2002;23:390-3. https://doi.org/10.1053/ajot.2002.126323.

14. Mizutamari M, Sei A, Fujimoto T, Taniwaki T, Mizuta H. L5 radiculopathy caused by a ganglion cyst of the posterior longitudinal ligament in a teenager. Spine J. 2009;9:e11-4. https://doi. org/10.1016/j.spinee.2008.05.013.

15. Cohen-Gadol AA, White JB, Lynch JJ, Miller GM, Krauss WE Synovial cysts of the thoracic spine. J Neurosurg. 2004;101:52-7. https://doi.org/10.3171/spi.2004.1.1.0052.

16. Vanhoenacker FM, Eyselbergs M, Van Hul E, Van Dyck P, De Schepper AM. Pseudotumoural soft tissue lesions of the hand and wrist: a pictorial review. Insights Imaging. 2011;2:319-33. https:// doi.org/10.1007/s13244-011-0076-5.

17. Cheng WY, Shen CC, Wen MC. Ganglion cyst of the cervical spine presenting with Brown-Sequard syndrome. J Clin Neurosci. 2006;13:1041-5. https://doi.org/10.1016/j.jocn.2005.07.028.

18. Kurz LT, Garfin SR, Unger AS, Thorne RP, Rothman RH. Intraspinal synovial cyst causing sciatica. J Bone Jt Surg Ser A. 1985;67:865-71. https://doi.org/10.2106/00004623-19856706000006.

19. Cudlip S, Johnston F, Marsh H. Subaxial cervical synovial cyst presenting with myelopathy. J Neurosurg Spine. 2009;90:141-4. https://doi.org/10.3171/spi.1999.90.1.0141.

20. Arantes M, Silva RS, Romão H, Resende M, Moniz P, Honavar $\mathrm{M}$, et al. Spontaneous hemorrhage in a lumbar ganglion cyst. Spine (Phila Pa 1976). 2008;33:e521-4. https://doi.org/10.1097/ BRS.0b013e31817b6206.

21. Ramieri A, Domenicucci M, Seferi A, Paolini S, Petrozza V, Delfini R. Lumbar hemorrhagic synovial cysts: diagnosis, pathogenesis, and treatment. Report of 3 cases. Surg Neurol. 2006;65:385-90. https://doi.org/10.1016/j.surneu.2005.07.073.

22. Métellus P, Fuentes S, Adetchessi T, Levrier O, Flores-Parra I, Talianu D, et al. Retrospective study of 77 patients harbouring lumbar synovial cysts: Functional and neurological outcome. Acta Neurochir (Wien). 2006;148:4754. https://doi.org/10.1007/ s00701-005-0650-z.

23. Sabo RA, Tracy PT, Weinger JM. A series of 60 juxtafacet cysts: Clinical presentation, the role of spinal instability, and treatment. J Neurosurg. 1996;85:560-5. https://doi.org/10.3171/jns.1996.85.4. 0560.

24. Denis DR, Hirt D, Shah S, Lu DC, Holly LT. Minimally invasive surgery for lumbar synovial cysts with coexisting degenerative spondylolisthesis. Int J Spine Surg. 2016;10. https://doi.org/10. $14444 / 3037$. 